\title{
NURSES KNOWLEDGE, PRACTICE AND ATTITUDE REGARDING PREVENTIVE MEASURE OF BIOLOGICAL HAZARDS AT MANSOURA HEALTH INSURANCE HOSPITAL

\author{
Rania EL-Mohamady ${ }^{1}$, Amel I Ahmed, ${ }^{2}$ Rabab G.Abdel-Kader ${ }^{3}$ \\ ${ }^{1}$ Nursing supervisor Mansoura Health Insurance Hospital \\ ${ }^{2,3}$ The Department of Community Health Nursing, Faculty of Nursing, Mansoura University
}

\begin{abstract}
:
Biological hazards are one of the most common health risks and the most harmful exposure to health care professionals. Health care professionals are constantly exposed to microorganisms that can cause serious or even lethal infections. Nurses in particular are often exposed to various infections during the course of carrying out their activities. Therefore, nurses should have sound knowledge and strict adherence to infection control practice. Aim: This study aimed to assess nurses' knowledge, practice and attitude regarding preventive measure of biological hazards. Design: Case study design was used and conducted on 141 of nurses working at Mansoura Health Insurance Hospital. Four structured questionnaire were used throughout the study for exploring nurses demographic data and occupational characteristics, their knowledge, practice and attitude related to biological hazards. Results: The majority of nurses $(85.8 \%)$ had positive attitude regarding to preventive measures of infection, while $14.2 \%$ of nurses had negative attitude. The study showed insignificant negative correlation with educations, and years of experience, there was a significant positive correlation between total knowledge score and total attitude score. The study showed that all of the nurses had unsatisfactory practice related to infection control measures. Conclusion: It is necessary to assess nurses' knowledge, practice, and attitude regarding preventive measure of biological hazards to reduce varied unacceptable nurse's practice and raise quality of care. There is a need for educational program about universal precautions especially about handling of the sharps.
\end{abstract}

Keywords: Biological hazards, knowledge, practice, attitude, preventive measure.

\section{Introduction: \\ INTRODUCTION}

Biological hazards are natural substances that include pathogens, infections, crevices and biodynamic substances (Abdulraheem, 2012). Exposure to biological hazards at work place could result in a remarkable number of work-related illnesses (Adler, 2011). Approximately 320,000 deaths occurs annually from communicable diseases are caused by work-related exposures to biological hazards (OSHA, 2012). The World Health Organization (WHO, 2011) reported that thirty five million of healthcare workers (HCWs), have percutenous exposure to infectious diseases annually. Healthcare workers have contact with infected patients and their body fluids. A particularly imperative element is the execution of exposure procedures, which will cause injuries to personnel. Injuries to health workers related to sharp objects are among the most frequently reported occupational accidents in health care (Hamid, 2010).

Globally needle stick injuries resulting in $37.6 \%$ of hepatitis $\mathrm{B}, 39 \%$ of hepatitis $\mathrm{C}$ and $4 \%$ of HIV /AIDS among 
health professionals (CDC, 2010). Most of these infections occur in developing countries in the health care unit as a result of exposure to percutaneous activity (Amira et al, 2014). Health workers in Africa endure two to four needle-stick injuries (NSIs) annually on the average with the African country and the Republic of South Africa reaching an average humanitarian outreach (Mashoto, 2015). According to the WHO (2011), about 150 million individuals worldwide are chronically infected with $\mathrm{HCV}$ and viral hepatitis causes 350,000 deaths a year. The occurrence of HBV and HCV in Egypt is excessive and dangerous injection transmission is the greater part of those contaminations. Thus, the threat of NSIs and related contaminations is the highest in Egypt contrasted with alternative nations (Hanafi, 2011)

Infection control measures, such as appropriate hand hygiene and the correct application of basic precautions during invasive procedures are simple and of lowcost, but require staff accountability and behavioral change, in addition to improving staff education, reporting and surveillance systems. To utilize these precautions, the human element plays an important role in increasing or decreasing the chances of catching health care acquired infection (HCAI) (Bouallègue et al, 2013).

Nurses should provide personnel with sufficient quantities of the appropriate protective clothing and all other personal protective equipment (PPE), especially fine, impermeable, hypoallergenic gloves. They must also ensure that these materials are regularly disinfected, cleaned and, where indicated, mended or repaired. Workers' representatives shall be consulted before a decision on the use of protective equipment is. If work clothes become contaminated they should be changed and then disinfected and cleaned by the employer. Nurses are obliged to use the protective wear and equipment provided. Nurses should not be allowed to take protective wear home for the purpose of washing. Admission to staff lounges, rest areas and canteens is not permitted to personnel wearing protective wear. (Reda,2010)

Significance of the Study: It has been documented in several epidemiological studies that healthcare workers such as physicians, and nurses are implicated in the transmission of infections. Literature that has explored the knowledge and practices of nurses is limited. Therefore, it is important to further investigate the impact of knowledge and practices of nurses with regard to the degree of the infection control. Assessing compliance with infection control measures in any health care setting is vital. Regular updating and strengthening of infection control practices should be one of the priority function of any place where health services are rendered.

Aim of the study : The present study aimed to assess nurses' knowledge, practice and attitude regarding preventive measure of biological hazards at Mansoura health insurance hospital.

\section{Subjects and Methods}

Study Design: Case study design was used in this study. That enabled the researcher to closely investigate the data within a specific context in the selected hospital (Zainal, 2007).

Setting: The study was conducted at Mansoura Health Insurance Hospital (M.H.I). This hospital presented at north east of Delta region, provides care for all patient who have health insurance with total bed capacity (360).

\section{Subjects of the study}

All nurses working at $\mathrm{M}$ H.I. were involved in the study ( $\mathrm{n}=155$ nurses). Actually 14 nurses involved in the pilot study and 141 nurse were involved in the main study. The 141 nurses were divided into 4 main groups. Each group included 
36 nurses. Each main group was divided into three sub-groups, each sub-group was observed three times throughout the 24 hours shift. Data collection tools:

The data of the study were collected by using four tools. The first tool was: Nurse Self- administered demographic and occupational questionnaire: It was used to assess demographic characteristic of nurses such as; age, sex, and educational level and occupational data of nurses such as: current job, setting of work, years of experience, and training program attended during work. The second tool was Nurse Self- administered knowledge assessment questionnaire: It was used to assess nurses' knowledge regarding biological hazards and protective safety measures. It consisted of 39 items divided into 5 major elements namely; definition of biological hazards(1 question), causes of biohazards(10 question) ,source of exposure(10 question), diseases related to biohazards (11 question) and preventive measures of biohazards(12 question). The total scores of the knowledge was categorized into poor knowledge level< $50 \%$ of total scores , fair knowledge level from $50 \%$ to less than $75 \%$ of total sores and good knowledge level $\geq 75 \%$ and more of total scores. The third tool was Nurse Selfadministered attitude Scale: It was used to assess nurses attitude toward biological hazards. It consists of 29 items requiring a response by using likert -rating scale with five continuum (strongly disagree, somewhat disagree, undecided, somewhat agree, strongly agree). A scoring system was used to quantify nurses positive attitude, in which positive statement were rated on the likert scale to be five for strongly agree and one for strongly disagree. The negative statements were rated on the likert scale to be one for strongly agree and five for strongly disagree. The fourth tool was Nurse Practice observation checklist: It was used to observe nurses practice of different procedure . It included 36 items divided into three major elements namely; hand washing, using personal protective equipment and disposal of sharps in safety containers. The total scores of practice was categorized into satisfactory level of practice $\geq 70 \%$ and Unsatisfactory level of practice $<70 \%$.

\section{Method}

\section{Administrative process}

An official permission was issued from ethical committee in the faculty of Nursing Mansoura University to carry out the study. Before conducting the study, an official permission was obtained from the Faculty of Nursing Mansoura University to be submitted to Mansoura health insurance hospital to obtain approval to conduct the study.

Tools of data of collection were developed based on reviewing the relevant literature. The developed data collection tools were tested for its content validity by submitting the tools to experts in community health nursing department who had experience in infection prevention and control. A Pilot study was conducted on $10 \%$ of nurses (14 nurses) who were selected randomly and excluded from the studied sample to evaluate the clarity, applicability. Accordingly, the necessary modification was done, some questions were added, and others were clarified or omitted. The reliability of the attitude scale as measured by using the Cronbach's alpha test was 0.844 .

\section{Data collection:}

All self -administered questionnaires were distributed to the studied nurses for obtaining demographic and occupational data, assessing their knowledge and attitude in relation to biological hazards. On the other hand, nurses were directly observed for their application of infection control measures 
Rania EL-Mohamady, et. al.

\begin{abstract}
by using observational checklist. Structured direct participatory observational technique was used in observing the nurses. All nurses (144) were divided into 4 main groups. Each group included 36 nurses that was divided into three sub-groups, each sub-group was observed three times throughout the 24 hours shift.
\end{abstract}

\section{Statistical analysis}

Data was analyzed with stand for statistical protect and service solution (SPSS) software version 20 .The quantitative data were described using numbers and percent. Continuous variable were presented as mean \pm standard deviation. Person correlation coefficient was used to estimate the correlation between knowledge, practice, and attitude of nurses regarding biological hazards and its preventive measures. The $p$ value of $\leq 0.05$ indicated a significant result.

\section{Results}

Table (1) shows demographic and occupational characteristics of studied nurses. All nurses were female and their age ranged from 20 years to less than 40 years, with mean age of $26.45 \pm 3.62$ years. Less than half of nurses $(41.8 \%)$ had diploma degree, $44.7 \%$ of nurses had technical institute, while only $13.5 \%$ had bachelor degree of nursing. About two third $63.1 \%$ of nurses did not attend any training program, while only $13.5 \%$ of them attended infection control training program.
Table(1): Distribution of nurses according to their demographic and occupational characteristics.

\begin{tabular}{|c|c|c|}
\hline Items & $\begin{array}{c}N \\
(\mathbf{1 4 1})\end{array}$ & $\%$ \\
\hline \multicolumn{3}{|l|}{ Age (years) } \\
\hline $20-<25$ & 61 & 43.3 \\
\hline $25-<30$ & 41 & 29.1 \\
\hline $30<35$ & 39 & 27.6 \\
\hline$\square \pm$ SD & \multicolumn{2}{|c|}{$3.6226 .45 \pm$} \\
\hline \multicolumn{3}{|l|}{ Educational level } \\
\hline Diploma of nursing & 59 & 41.8 \\
\hline $\begin{array}{l}\text { Diploma of } \\
\text { Technical Nursing } \\
\text { Institute }\end{array}$ & 63 & 44.7 \\
\hline $\begin{array}{l}\text { Bachelor of } \\
\text { nursing }\end{array}$ & 19 & 13.5 \\
\hline \multicolumn{3}{|l|}{ Occupation } \\
\hline Bedside nurse & 120 & 85.1 \\
\hline Head nurse & 15 & 10.6 \\
\hline Supervisor & 6 & 4.3 \\
\hline \multicolumn{3}{|l|}{ Years of experience } \\
\hline$<5$ & 62 & 43.9 \\
\hline $5-<10$ & 28 & 19.9 \\
\hline 10- and more & 51 & 36.2 \\
\hline$\square \pm$ SD & \multicolumn{2}{|c|}{$6.74 \pm 4.38$} \\
\hline \multicolumn{3}{|l|}{ Department } \\
\hline Medical & 47 & 33.3 \\
\hline Surgical & 34 & 24.1 \\
\hline Other & 60 & 42.6 \\
\hline \multicolumn{3}{|l|}{ Training program } \\
\hline None & 89 & 63.1 \\
\hline Infection control & 19 & 13.5 \\
\hline Other & 33 & 23.4 \\
\hline \multicolumn{3}{|c|}{$\begin{array}{l}* \text { Other department (ICU, operation, } \\
\text { dialysis) } \\
\text { CPR (cardiac pulmonary } \\
\text { Resuscitation) } \\
\text { Other training program (CPR, Blood } \\
\text { transfusion) }\end{array}$} \\
\hline
\end{tabular}


NURSES KNOWLEDGE, PRACTICE AND ATTITUDE etc...

Table (2) shows the nurses' level of knowledge regarding to biological hazards. Table indicates that $97.2 \%$ of nurses showed good level of knowledge about definition of biological hazards with mean \pm SD $(0.97 \pm 0.17)$. Regarding to the causes, sources of biological hazards and

Table (2) Distribution of nurses according to their level of knowledge regarding biological hazards

\begin{tabular}{|c|c|c|c|c|c|c|}
\hline \multirow{2}{*}{ Items } & \multicolumn{2}{|c|}{$($ Poor < 50\%) } & \multicolumn{2}{|c|}{ (Fair 50\% - 75\%) } & \multicolumn{2}{|c|}{$(\operatorname{Good} \geq 75 \%)$} \\
\hline & $\mathbf{N}$ & $\%$ & $\mathbf{N}$ & $\%$ & $\mathbf{N}$ & $\%$ \\
\hline $\begin{array}{l}\text { Definition of } \\
\text { biological hazards } \\
\text { score }\end{array}$ & 4 & 2.8 & 0 & 0 & 137 & 97.2 \\
\hline$\square \pm$ SD & \multicolumn{6}{|c|}{$0.97 \pm 0.17$} \\
\hline $\begin{array}{l}\text { causes of biological } \\
\text { hazards score }\end{array}$ & 8 & 5.7 & 16 & 11.3 & 117 & 83.0 \\
\hline$\square \pm \mathrm{SD}$ & \multicolumn{6}{|c|}{$8.64 \pm 1.93$} \\
\hline $\begin{array}{l}\text { sources of biological } \\
\text { hazards score }\end{array}$ & 1 & 0.7 & 17 & 12.1 & 123 & 87.2 \\
\hline$\square \pm \mathrm{SD}$ & \multicolumn{6}{|c|}{$8.22 \pm 1.15$} \\
\hline $\begin{array}{l}\text { Disease related to } \\
\text { biological hazard } \\
\text { score }\end{array}$ & 11 & 7.8 & 15 & 10.6 & 115 & 81.6 \\
\hline$\square \pm \mathrm{SD}$ & \multicolumn{6}{|c|}{$9.49 \pm 2.12$} \\
\hline $\begin{array}{l}\text { prevention of bio } \\
\text { logical hazards } \\
\text { score }\end{array}$ & 2 & 1.4 & 58 & 41.1 & 81 & 57.4 \\
\hline$\square \pm$ SD & \multicolumn{6}{|c|}{$10.52 \pm 1.72$} \\
\hline $\begin{array}{l}\text { Total knowledge } \\
\text { score }\end{array}$ & 2 & 1.4 & 7 & 5.0 & 132 & 93.6 \\
\hline$\square \pm \mathrm{SD}$ & \multicolumn{6}{|c|}{$37.84 \pm 4.68$} \\
\hline
\end{tabular}

Table (3) shows the level of nurses observed practice related to the application of preventive measures of biological hazards. The majority of nurses showed unsatisfactory practice level related to hand washing during the three shifts. In the morning shift, nurses showed unsatisfactory level of hand washing $88.6 \%$ and afternoon $94.3 \%$, while in night $85.1 \%$. For example, nurses did not wash their hands before and after any interference with patient. This related unavailability of to sinks, or their inconvenient place, in addition to lack of soap, and towels. As regards to personal their related diseases $83.0 \%, 87.2 \%$ and $81.6 \%$ showed a good level of knowledge with mean scores $8.64 \pm 1.93,8.22+1.15$ and $9.49 \pm 2.12$ respectively. While only $57.4 \%$ had a good knowledge about preventive measure of biological hazards. protective measure the majority of nurses showed unsatisfactory practice level among $96.4 \%$ of nurses in night shift $92.9 \%$ in after noon shift and $90.0 \%$ in morning shift. Regarding safe handling of wastes, the majority of nurses showed unsatisfactory practice level in the three shifts due to shortage of nurses. This mistake could be summarized in recapping needle after used, improper dealing with blood and waste product. 
Table (3) Distribution of nurses according to their level of practice about hand washing, personal protective measures and safe handling

\begin{tabular}{|l|c|c|c|c|}
\hline Items & (Unsatisfactory $<70 \%)$ & (Satisfactory $\geq 70 \%)$ \\
\hline Hand washing & $\mathbf{N}$ & $\mathbf{\%}$ & $\mathbf{N}$ & $\mathbf{\%}$ \\
\hline Morning & 125 & 88.6 & 16 & 11.3 \\
\hline After noon & 133 & 94.3 & 8 & 5.6 \\
\hline Night & 120 & 85.1 & 21 & 14.8 \\
\hline \multicolumn{7}{|c|}{ Using personal protective measure } \\
\hline Morning & 127 & 90.0 & 14 & 9.9 \\
\hline After noon & 131 & 92.9 & 10 & 7.0 \\
\hline Night & 136 & 96.4 & 5 & 3.5 \\
\hline \multicolumn{5}{|l|}{ Safe handling of wastes } \\
\hline Morning & 141 & 100 & 0 & 0 \\
\hline After noon & 141 & 100 & 0 & 0 \\
\hline Night & 141 & 100 & 0 & 0 \\
\hline \multicolumn{7}{|l|}{ Safe handling of sharps } \\
\hline Morning & 141 & 100 & 0 & 0 \\
\hline After noon & 141 & 100 & 0 & 0 \\
\hline Night & 141 & 100 & 0 & 0 \\
\hline
\end{tabular}

Tables $(4,5)$ show that attitude of nurses regarding biological hazards. The majority of nurses $(85.8 \%)$ had positive attitude related to infection control measures to prevent infection and spread of diseases, while $14.2 \%$ of nurses had negative attitude as some of health care worker mentioned that application of infection control measures take long time, need more effort, and applied only for patient with infectious diseases. 
NURSES KNOWLEDGE, PRACTICE AND ATTITUDE etc...

Table (4) Distribution of nurses according to their positive attitude regarding biological hazards

\begin{tabular}{|c|c|c|c|c|c|c|c|c|c|c|}
\hline \multirow{2}{*}{ Items } & \multicolumn{2}{|c|}{$\begin{array}{l}\text { Strongly } \\
\text { disagree }\end{array}$} & \multicolumn{2}{|c|}{ Disagree } & \multicolumn{2}{|c|}{ Not sure } & \multicolumn{2}{|c|}{ Agree } & \multicolumn{2}{|c|}{ Strongly agree } \\
\hline & $\mathbf{N}$ & $\%$ & $\mathbf{N}$ & $\%$ & $\mathbf{N}$ & $\%$ & $\mathbf{N}$ & $\%$ & $\mathbf{N}$ & $\%$ \\
\hline $\begin{array}{l}\text { Positive attitude } \\
\text { Follow infection control guidelines } \\
\text { protect from injury at work }\end{array}$ & 0 & 0 & 0 & 0 & 2 & 1.4 & 17 & 12.2 & 122 & 86.5 \\
\hline $\begin{array}{l}\text { Infection control guidelines help, } \\
\text { provide the best care for the patient. }\end{array}$ & 2 & 1.4 & 2 & 1.4 & 0 & 0 & 37 & 26.2 & 100 & 70.9 \\
\hline $\begin{array}{l}\text { Use infection control guidelines when } \\
\text { dealing with each patient to minimize } \\
\text { transmission of infection }\end{array}$ & 0 & 0 & 4 & 2.8 & 0 & 0 & 30 & 21.3 & 107 & 75.9 \\
\hline $\begin{array}{l}\text { Infection control guidelines can } \\
\text { prevent the spread of infection from } \\
\text { the patient to health workers and vice } \\
\text { versa }\end{array}$ & 2 & 1.4 & 0 & 0 & 4 & 2.8 & 27 & 19.1 & 108 & 76.6 \\
\hline $\begin{array}{l}\text { All health care providers must be } \\
\text { ensured with availability of adequate } \\
\text { protection when doing any action }\end{array}$ & 2 & 1.4 & 0 & 0 & 9 & 6.4 & 44 & 31.2 & 86 & 61.0 \\
\hline $\begin{array}{l}\text { Medical and non-medical waste } \\
\text { separation is useful in preventing the } \\
\text { transmission of infection. }\end{array}$ & 0 & 0 & 1 & 1.7 & 0 & 0 & 28 & 19.9 & 112 & 79.4 \\
\hline $\begin{array}{l}\text { General waste should be disposed in } \\
\text { black bags }\end{array}$ & 3 & 2.1 & 0 & 0 & 0 & 0 & 33 & 23.4 & 105 & 74.5 \\
\hline $\begin{array}{l}\text { The disposal of needles as one unit } \\
\text { reduces the exposure to acupuncture }\end{array}$ & 0 & 0 & 6 & 4.3 & 12 & 8.5 & 19 & 13.5 & 104 & 73.8 \\
\hline $\begin{array}{l}\text { place safety containers close to work } \\
\text { reduces the exposure to acupuncture } \\
\text { and the spread of infection }\end{array}$ & 2 & 1.4 & 1 & 0.7 & 0 & 0 & 28 & 19.9 & 110 & 78.0 \\
\hline $\begin{array}{l}\text { It is necessary to use personal } \\
\text { protective equipment in case of } \\
\text { emergency }\end{array}$ & 9 & 6.4 & 1 & 0.7 & 2 & 1.4 & 44 & 31.2 & 85 & 60.3 \\
\hline $\begin{array}{l}\text { Infection control guidelines necessary } \\
\text { not touch technology to ensure that the } \\
\text { tools remain sterile while doing } \\
\text { nothing }\end{array}$ & 4 & 2.8 & 3 & 2.1 & 2 & 1.4 & 47 & 33.3 & 85 & 60.3 \\
\hline $\begin{array}{l}\text { It is necessary not sharing personal } \\
\text { protective equipment with any one }\end{array}$ & 9 & 6.4 & 22 & $\begin{array}{c}15 \\
6\end{array}$ & 12 & 8.5 & 21 & 14.9 & 77 & 60.3 \\
\hline $\begin{array}{l}\text { Wash hands before and after any } \\
\text { interference with the patient }\end{array}$ & 4 & 2.8 & 5 & 3.5 & 2 & 1.4 & 25 & 17.7 & 105 & 54.6 \\
\hline $\begin{array}{l}\text { Transmission of infectious organisms } \\
\text { can be reduced by adhering to the } \\
\text { principles of infection control }\end{array}$ & 0 & 0 & 4 & 2.8 & 12 & 8.5 & 35 & 24.8 & 90 & 63.8 \\
\hline $\begin{array}{l}\text { Cleansing should ensure that medical } \\
\text { equipment by all health care workers }\end{array}$ & 2 & 1.4 & 3 & 2.1 & 8 & 5.7 & 45 & 31.9 & 83 & 58.9 \\
\hline $\begin{array}{l}\text { Vaccination against infectious and } \\
\text { dangerous diseases helps to minimize } \\
\text { biological risks }\end{array}$ & 0 & 0 & 0 & 0 & 3 & 2.1 & 47 & 33.3 & 91 & 64.5 \\
\hline $\begin{array}{l}\text { Vaccination against hepatitis } \mathrm{B} \text { is } \\
\text { important }\end{array}$ & 0 & 0 & 2 & 1.4 & 2 & 1.4 & 26 & 18.4 & 111 & 78.7 \\
\hline Total attitude score ( $\square \pm$ SD) & & & & & & & & & & \\
\hline
\end{tabular}


Rania EL-Mohamady, et. al.

Table (5) Distribution of nurses according to their negative attitude regarding biological hazards

\begin{tabular}{|c|c|c|c|c|c|c|c|c|c|c|}
\hline \multirow[t]{2}{*}{ Items } & \multicolumn{2}{|c|}{$\begin{array}{l}\text { Strongly } \\
\text { disagree }\end{array}$} & \multicolumn{2}{|c|}{ Disagree } & \multicolumn{2}{|c|}{ Not sure } & \multicolumn{2}{|c|}{ Agree } & \multicolumn{2}{|c|}{$\begin{array}{l}\text { Strongly } \\
\text { agree }\end{array}$} \\
\hline & $\mathbf{N}$ & $\%$ & $\mathbf{N}$ & $\%$ & $\mathbf{N}$ & $\%$ & $\mathbf{N}$ & $\%$ & $\mathbf{N}$ & $\%$ \\
\hline $\begin{array}{l}\text { Follow infection control } \\
\text { guidelines take a lot of time }\end{array}$ & 33 & 23.4 & 34 & 24.1 & 3 & 2.1 & 58 & 41.1 & 13 & 9.2 \\
\hline $\begin{array}{l}\text { Follow infection control } \\
\text { guidelines make the work hard }\end{array}$ & 27 & 19.1 & 22 & 15.6 & 9 & 6.4 & 75 & 53.2 & 8 & 5.7 \\
\hline $\begin{array}{lrr}\begin{array}{l}\text { Follow } \\
\text { practices }\end{array} & \begin{array}{r}\text { infection control } \\
\text { cumbersome and } \\
\text { uncomfortable }\end{array} \\
\end{array}$ & 31 & 22.0 & 18 & 12.8 & 17 & 12.1 & 57 & 40.4 & 18 & 12.8 \\
\hline $\begin{array}{l}\text { Infection control guidelines } \\
\text { consume a lot of effort }\end{array}$ & 36 & 25.5 & 35 & 24.8 & 15 & 10.6 & 42 & 29.8 & 13 & 9.2 \\
\hline $\begin{array}{l}\text { Infectious diseases can be } \\
\text { treated and thus are not } \\
\text { required to use protective } \\
\text { devices }\end{array}$ & 21 & 14.9 & 11 & 7.8 & 11 & 7.8 & 33 & 23.4 & 65 & 46.1 \\
\hline $\begin{array}{r}\text { Infection control practices } \\
\text { limited only to patients with } \\
\text { infectious diseases }\end{array}$ & 30 & 21.3 & 22 & 15.6 & 7 & 5.0 & 47 & 33.3 & 35 & 24.8 \\
\hline $\begin{array}{l}\text { Use of normal alcohol } \\
\text { alternative causes the stability } \\
\text { of the virus on the hands }\end{array}$ & 56 & 39.7 & 11 & 7.8 & 38 & 27.0 & 25 & 17.7 & 11 & 7.8 \\
\hline $\begin{array}{l}\text { Wear personal protective } \\
\text { equipment hinder the work }\end{array}$ & 31 & 22.0 & 7 & 5.0 & 15 & 10.6 & 61 & 43.3 & 27 & 19.1 \\
\hline $\begin{array}{l}\text { Use of personal protective } \\
\text { equipment may harm the } \\
\text { patient psychologically, so it } \\
\text { should not be used }\end{array}$ & 21 & 14.9 & 13 & 9.2 & 14 & 9.9 & 53 & 37.6 & 40 & 28.4 \\
\hline \begin{tabular}{l} 
Change gloves are not \\
necessary during the \\
procedures per patient if \\
\multicolumn{2}{c}{ contaminated significantly }
\end{tabular} & 32 & 22.7 & 8 & 5.7 & 8 & 5.7 & 57 & 40.4 & 36 & 25.5 \\
\hline $\begin{array}{r}\text { The telephones and doorknobs } \\
\text { in the wards is not a source of } \\
\text { infection }\end{array}$ & 38 & 27.0 & 13 & 9.2 & 22 & 15.6 & 53 & 37.6 & 15 & 10.6 \\
\hline $\begin{array}{l}\text { Use extra precautions for } \\
\text { patients with infectious } \\
\text { diseases is a waste of } \\
\end{array}$ & 56 & 41.8 & 12 & 8.5 & 13 & 9.2 & 39 & 27.7 & 18 & 12.8 \\
\hline Total attitude score $(\square \pm$ SD) & & & & & 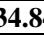 & 0.10 & & & & \\
\hline
\end{tabular}

Tables $(6,7)$ show insignificant negative correlation between education and experience. Results indicated significant positive correlation between total knowledge score, practice score, and total attitude score.

Table (6) Correlation between nurses' education and years of experience and their level of knowledge, practice, and attitude score

\begin{tabular}{|r|c|c|c|c|}
\hline \multirow{2}{*}{ Items } & \multicolumn{2}{|c|}{ Education } & \multicolumn{2}{c|}{ Experience } \\
\cline { 2 - 5 } & $\mathbf{r}$ & $\mathbf{p}$ & $\mathbf{r}$ & $\mathbf{p}$ \\
\hline Practice & -0.079 & 0.352 & -0.036 & 0.671 \\
\hline Knowledge & -0.50 & 0.556 & -0.034 & 0.691 \\
\hline Attitude & -0.002 & 0.979 & -0.057 & 0.502 \\
\hline
\end{tabular}


NURSES KNOWLEDGE, PRACTICE AND ATTITUDE etc...

Table (7) Correlation between nurses total knowledge score ,total practice score and total attitude score.

\begin{tabular}{|c|c|c|}
\hline \multirow{2}{*}{ Items } & \multicolumn{2}{|c|}{ Knowledge } \\
\cline { 2 - 3 } & $\mathbf{r}$ & $\mathbf{p}$ \\
\hline Practice & 0.170 & 0.044 \\
\hline Attitude & 0.173 & 0.040 \\
\hline
\end{tabular}

\section{Discussion}

Healthcare workers (HCWs) are at increase of catching blood- borne infections in their daily work throw job related factors. Globally, needle stick injuries (NSIs) are most common source of occupational exposures to blood which result in transmission of blood -borne infections (Amira, et al 2014). The present study found that the majority of nurses had a good level of knowledge in relation to blood borne pathogens. This was in agreement with other studies conducted at different countries revealed good knowledge regarding to occupational exposures to blood borne pathogens. The first study was conduct in Nigeria by Okechuku, (2012) and another study was conduct in India by Jain \& Dogra,( 2012). Regarding to nurses knowledge about definition of biological hazards, causes, sources and mode of transmission, the present study showed that nurses had good level of knowledge. Several studies reported that nurses were knowledgeable about definition of infection, causes, sources and mode of transmission (Talaat et al, 2010 and Ebied, 2011). Theses finding were consistent with the results of the current study and with other study conducted at Egyptian neonatal intensive care unit, which found that Egyptian nurses were knowledgeable about definition of infection and different mode of transmission Ibrahim et al, (2011). Concerning preventive measures about biological hazards, the current study demonstrated that the majority of studied nurses had good knowledge related to preventive measure. These results at the same line with Ford, (2011 )who found that the most of healthcare workers were aware about safety precaution against occupational biological hazards, complete immunization against Hepatitis B virus and post-exposure prophylaxis.

As regards to the level of practice, the present study showed that the most of nurses had unsatisfactory practice regarding to hand washing, using of personal protective equipment, and safe handling of contaminated materials. This study was in agreement with other studies that were conducted in India and Vietnam Manisha, (2012) and Thu, (2012). Hand hygiene is the first step towards effective infection control in any health facility. The present study showed that hand washing was rarely done before and after getting in contact with and removing the gloves. This was in agreement with Suchitra, (2007) and Manisha,( 2012 )who found that the most common reasons reported for poor adherence to hand hygiene were the inconvenient placed sinks, followed by lack of soap/water, and insufficient time. Some of reported leading practices to exposure to biological hazards were needle recapping after used, improper handling of blood and waste product.

The unsatisfactory infection control practice of nurses in the current study may be referred to the insufficient continuous education, as around two -third of nurses did not attend any training program. The present study revealed that this finding is consistent with two studies. The first study conduct by Nagaraju, (2013) among healthcare providers working in PHCs of Bagepalli Taluk found who that about two- third of the studied healthcare providers would never attend any continuing education course. The second study was conduct by 
Fashafsheh, (2015) among nursing staff in the palastinian hospitals, the study revealed that the majority of healthcare providers $(83 \%)$ did not attend any training program. Both studies showed that healthcare workers rarely wash their hands before and after attending contacting a patient, or after having contacting body fluids. In addition, they were not use personal protective equipment (PPE) adequately.

As regards to the of attitude of nurses toward biological hazards and their protective measures, the present study revealed that most of nurses had a positive attitude towards adherence to infection control measures that control exposure to biological hazards with mean scores of (77.83 \pm 5.16). These results agreed with study conduct by Picheansathian, (2008) who reported that respondents had positive attitude toward infection control measures. In addition, Patel, (2012) in a tertiary health care center in India reported a positive attitude of $60 \%$ of nurses for safe collection measures and final disposal of biomedical waste. On the other hand, nearly half of nurses of the current study showed a negative attitude toward controlling measures of biological hazards because of limited time and over work load. This result agreed with the study conduct by Magoro, (2012) and Nour, (2015) who reported that a negative attitude among health care providers toward infection control measures.

Concerning the correlation between knowledge and practice, the present study showed a significant positive correlation between nurses' knowledge and practice. This was in agreement with several studies which revealed a statistically significant positive correlation between knowledge and practice of universal precautions.( Whyte, 2009. Khan , 2014, Almutairi , 2015, Ndikom, \& Onibokun, 2007, Hamid , 2010, Eskander,2013)
Conclusion and Recommendation

The study concluded that nurses working at the Mansoura Health Insurance Hospital have good level of knowledge regarding biological hazards and their preventive measures. They have a positive attitude towards adherence to infection control measures that control exposure to biological hazards. However, nurses show unsatisfactory practice of preventive measures of biological hazards. The lack of resources and inappropriate required infrastructure for hand hygiene in particular are the main reasons of poor adherence to hand hygiene and using of personal protective measures.

1. A periodic and ongoing reorientation program regarding universal precautions is essential for preventing the hospitalacquired infections

2. Infection control committee of hospital should take initiative to improve hand hygiene and provide required resources

3. Efficient supervision for implementing preventive measures would be strengthened

\section{Reference;}

1. Adler, J. (2011). Emergency medicine articles (including Plant poisoning, caladium, dieffenbachia, and philodendron; Mushroom toxicity; and various snake, spider and scorpion envenomation articles). WebMD. Retrieved from http://emedicine.medscape.com/emerg ency_medicine

2. Amira, C.O. \& Awobusuyi, J.O. (2014) Needle-stick injury among health care workers in hemodialysis units in Nigeria: a multi-center study. International Journal of Occupational Medicine and EnvironmentalHealth5, 1-8.

3. Abdulraheem IS, Amodu MO, Saka MJ, Bolarinwa OA, Uthman MMB. (2012). Knowledge, Awareness and Compliance with Standard Precautions 
NURSES KNOWLEDGE, PRACTICE AND ATTITUDE etc...

among Health Workers in North Eastearn Nigeria. J. Community Med Health Edu 2:131. doi:10.4172/jcmhe.1000131.

4. Almutairi KM, Al Helih EM, Moussa M, Boshaiqah AE, Saleh Alajilan A, Vinluan JM, Almutairi A. ( 2015). Awareness, attitudes, and practices related to coronavirus pandemic among public in Saudi Arabia. Fam Commun Health, 38(4):332-340.

5. CDC. (2010). Recommendations for prevention of transmission of Immunodeficiency Virus

6. and Hepatitis B Virus to health care and public safety workers. MMWR 38 .

7. Eskander H., Morsy W., Elfeky H. (2013) Intensive Care Nurses' Knowledge \& Practices regarding Infection Control Standard Precautions at a Selected Egyptian Cancer Hospital. Journal of Education and Practice; 4 (19): 160- 174

8. Ebied, E. (2011). Impact of bloodborne diseases prevention program on compliance with infection control standard precautions among nurses in family health centers, El Fayoum Governorate, Egypt.

9. Ford MT, Tetrick LE.( 2011), Relations among occupational hazards, attitudes, and safety performance. J Occup Health Psychol.;16(1):48-66.

10. Hamid M.Z.A., Aziz N.A., Anita A.R., Norlijah O. (2010). Knowledge of blood-borne infectious diseases and the practice of universal precautions amongst health-care workers in a tertiary hospital in malaysia. Southeast Asian J Trop Med Public Health, 41(5): 1192-1199.

11. Imad Fashafsheh Mr. Ahmad Ayed* Mrs. Faeda Eqtait Mrs. Lubna Harazneh .(2015): Knowledge and Practice of Nursing Staff towards Infection Control Measures in the
Palestinian Hospitals, Journal of

Education and Practice, Vol.6, No.4.

12. Ibrahim, Y.S, Said A.M, Hamdy G.K. (2011), Assessment of infection control practices in neonatal intensive care unit. The Egyptian Journal of Community medicine; 29(4):27-45

13. 1Jain M., Dogra V., et.al. (2012). Infection control practices among doctors and nurses in a tertiary care hospital. Ann Trop Med Pub Health, 5:29-33.

14. Khan MU, Shah S, Ahmad A, Fatokun O ( 2014). Knowledge and attitude of healthcare workers about middle east respiratory syndrome in multispecialty hospitals of Qassim, Saudi Arabia. BMC Public Health, 14(1):1281.

15. Manisha J., Vinita D., Bibhabati M., Archana T., Poonam S., L. (2012): Infection control practices among doctors and nurses in a tertiary care hospital. Department of Microbiology, G.B. Pant Hospital, New Delhi, India Year: 2012 | Volume: 5 Issue: 1|Page: 29-33.

16. Mashoto, K.O., Mubyazi, G.M., Mohamed, H. \& Malebo, H.M. (2013): Self-reported occupational exposure to HIV and factors influencing its management practice: a study of healthcare workers in Tumbi and DodomaHospitals, Tanzania.BMC Health Services Research13, 276.

17. Magro, F. (2012): Knowledge, Attitude and practice regarding personal protective equipment amongest Stevens lumber employees in the Capricorn District of L IMPOPO PROVINCE, SOUTH AFRICA.

18. M.I. Hanafi,1 A.M. Mohamed,1 M.S. Kassem2 and M. Shawki1. (2011): Needlestick injuries among health care workers of University of Alexandria hospitals, Eastern Mediterranean Health Journal, vol 11. 
19. Mohamed O. Nour1,3*, Ahmed O. Babilghith2, Hatim A. Natto1, Fowzi O. Al-Amin1 and Sallahaldeen M. Alawneh1. (2015) : Knowledge, attitude and practices of healthcare providers towards MERS-CoV infection at Makkah hospitals, KSA, International Research Journal of Medicine and Medical Sciences Vol. 3(4), pp. 103-112.

20. Nagaraju B1, Padmavathi GV2, Puranik DS3, Shantharaj MP4 Sampulatha SP5*. (2013) : A study to assess the knowledge and practice on bio-medical waste management among the health care providers working in PHCs of Bagepalli Taluk ,India, with the view to prepare informational booklet, International Journal of Medicine and Biomedical Research Volume 2 Issue 1 January - April 2013

21. OSHA. (2012): Expert Forecast on Emerging Biological Risks related to Occupational Safety and Health. European Agency for Safety and Health at Work. Luxembourg: Office for Official Publications of the European Communities.

22. Okechuku E.F., et.al. (2012). Knowledge, practice of standard precautions in public health care facilities, Abuja, Nigeria.

23. Picheansathian W, Pearson A, Suchaxaya P. (2008): The effectiveness of a promotion programmers on hand hygiene compliance and nosocomial infections in a neonatal intensive care unit. International Journal of Nursing Practice. Aug;14(4):315-21
24. Suchitra, J.B. and N.D. Lakshmi, (2007): Impact Of Education On Knowledge, Attitude And Practices Among Various Categories Of Health Care Workers On Nosocomial Infections. Indian J. Medical Microbiol., 25(3): 181

25. Thu TA, Anh NQ, Chau NQ, Hung NV. ( 2012): Knowledge, attitude and practices regarding standard and isolation precautions among Vietnamese health care workers: A multicenter cross-sectional survey. Intern Med, 2(4):115

26. Talaat E, Shamia E. (2010) : Developing a control action plan for infection prevention at the endoscopy unit. Journal of international Academic research. Jjuly ;2(4): 412-420

27.-World Health Organization [WHO]. (2011) HIV/AIDS in3. work place. [cited April 2011]. Available from:

http://www.who.int/occupational_healt h/topics/hiva ids/en/

28. Whyte J, Ward, P, Eccles DW. (2009). The Relationship Between Knowledge and Clinical Performance in Novice and Experienced Critical Care Nurses. Heart Lung ;38:517-525

29. Zainal, Z. (2007). Case study as a research method. Jurnal Kemanusiaan bil.9, p1-6 